\title{
Positive Effect of Biochar Derived from Argan Waste on Soil Nutrients and Growth of Three Plants
}

\author{
Laila Bouqbis $^{1 *}$, Salma Daoud ${ }^{2}$, Moulay Cherif Harrouni ${ }^{3}$ \\ 1 Faculty of applied sciences, Ibn Zohr University, Agadir, Morocco \\ 2 Faculty of sciences, Ibn Zohr University, Agadir, Morocco \\ 3 Hassan II Agronomic and Veterinary Institute, Agadir, Morocco \\ Corresponding author's e-mail: I.bouqbis@uiz.ac.ma
}

\begin{abstract}
The lack of organic matter content in deteriorated soils in drought stricken areas is a serious problem for vegetation cover. The use of organic amendments like biochar and compost to agricultural soils could be a good remedy for poor soil, water deficiency and plants growth. The comparative analysis of the effects of biochar produced from argan shells, compost and their mixture on the growth of quinoa (Chenopodium quinoa), sugar beet (Beta vulgaris) and alfalfa (Medicago sativa) was the main objective of this research. It was assumed that the addition of biochar mixed with compost could enhance soil fertility and then improve crop productivity of plants. For this purpose, three treatments $(2 \%, 4 \%$ and $6 \%)$ of biochar $(\mathrm{B})$, compost $(\mathrm{C})$ and biochar-compost $(\mathrm{B}-\mathrm{C})$ mixture were applied to soil. The samples for different treatments were collected, incubated and then analyzed. In order to evaluate the plant growth, the greenhouse experiments were conducted for three months in the pots filled with untreated and treated soils. The results showed that the addition of biochar and compost to soil increased $\mathrm{pH}$, electrical conductivity, exchangeable cations, total nitrogen, phosphorus, total organic matter and cation exchange capacity. A significant improvement of the biomass of plants has been observed when applying a mixture of biochar and compost at $6 \%$ for quinoa and sugar beet and at $4 \%$ for alfalfa. According to the obtained results, mixing argan biochar with compost has a positive impact on soil nutrients and growth of plants.
\end{abstract}

Keywords: argan shells biochar, compost, nutrient contents, plants growth, poor soil

\section{INTRODUCTION}

Crop production is intensely constrained by poor soil conditions in the areas characterized by low water shortage, which results in the degradation of agricultural territories (Perez-Esteban et al., 2012, Mills et al., 2014, Amini et al., 2016). In fact, the south of Morocco is subject to severely dry arid climate which hinders the plant growth (Badraoui et al., 2000, Schlesinger et al., 2015). Under these hard climate conditions, addition of mineral fertilizers did not have a profitable effect (Agegnehu et al., 2016). Hence, biochar and compost, two organic amendments, can be applied for improving the soil structure and as a nutrient source for plant biomass production (Solaiman and Anawar, 2015, Lim et al., 2016, Ramzani et al., 2016, Li et al., 2018). However, biochar and compost-biochar combination in some studies revealed the negative effects which have been related to the type of biochar and soil properties (Jones et al., 2012, Rajkovich et al., 2012, Schmidt et al., 2014, Butnan et al., 2015, Haider et al., 2017). Moreover, to determine the most adequate biochar percentage, it could be necessary to investigate the effects of different doses prior to carrying out large scale field experiments.

Thus, the soil was treated with argan biochar, compost and compost-biochar mixture before being vegetated with quinoa (Chenopodium quinoa), sugar beet (Beta vulgaris) and alfalfa (Medicago sativa). The purpose was to verify whether using argan biochar and compost in mixtures ameliorates plant biomass production. 


\section{MATERIALS AND METHODS}

\section{Analysis of growth media samples}

The biochar used was prepared from argan shells waste which were combusted in a pyrolytic stove made in Morocco based on the model provided by Dr. Claudia Kammann (Institute for Plant Ecology, Giessen University, Germany) (Bouqbis et al., 2016). The compost from varied vegetable organic matter, bought from commercial vendors in Morocco, was provided with soil by Dr. Harrouni (Hassan II Agronomic and Veterinary Institute (IAV)). After preparing varied treatments, and incubating the samples for 4 weeks, their physicochemical properties were measured in IAV soil science laboratory using standard analytical methods. The $\mathrm{pH}$ and electrical conductivity (EC) were both measured in water extracts with standard electrodes (Blakemore et al., 1987). For chemical analysis, the total concentration of $\mathrm{Na}, \mathrm{K}, \mathrm{Ca}$ and $\mathrm{Mg}$ were determined by flame emission spectrophotometer (Van Ranst et al., 1999), whereas $\mathrm{Fe}, \mathrm{Mn}, \mathrm{Zn}$ and $\mathrm{Cu}$ by atomic absorption spectrophotometer (Lindsay and Norvell, 1978) and colorimetrically for $\mathrm{NaNO}_{3}$ and $\mathrm{KH}_{2} \mathrm{PO}_{4}$ (Blakemore et al., 1987). Cation exchange capacity (CEC) was determined by means of the ammonium acetate method (Metson, 1956). The total soil organic carbon and the total nitrogen (TN) content were measured using Walkley-black method and the Kjeldahl method, respectively.

\section{Plant growing protocol}

In this test, argan shells biochar and compost were added to $2000 \mathrm{ml}$ of dried soil in four concentrations $(0 ; 2 ; 4$ and 6 percent $\mathrm{v} / \mathrm{v} ; \mathrm{n}=3)$ which means that $2 \%$ corresponds to a mixture of $2 \mathrm{ml}$ dry biochar with $98 \mathrm{ml}$ dry soil without using any fertilizers in the mixtures. The use of volumetric mixtures permitted a comparable testing of biochar and compost, and their combination in this pot study. The experiment was carried out in black poly plastic bags purchased from commercial vendors in Morocco (inner diameter $13 \mathrm{~cm}$, height $20 \mathrm{~cm}$, with eight draining holes round each bag) which were filled with soil (S), soil+biochar (S-B), soil+compost (S-C) and soil+compost+biochar (S-C-B) applying the four concentrations mentioned above and planted with quinoa, sugar beet and alfalfa. The seeds were first germinated in seed beds and when the first leaves appeared, three germinated seeds were then replaced in the pots. For each plant, 30 pots were prepared ( 9 pots per treatment with three replicates). The water holding capacity was determined for each mixture and adjusted on 60 percent. During the test, the water loss was controlled and adjusted regularly. The experiment was conducted for 3 months in the greenhouse. Then, the plants height was determined and the fresh biomass of leaves, shoots and seeds were weighed immediately. The roots were subsequently carefully washed and weighted after drying. After $48 \mathrm{~h}$ at $80^{\circ} \mathrm{C}$ oven drying, the dry mass was weighed. One-way analysis of variance (SigmaPlot Software, Systat Inc.; Chicago, IL, USA) was performed to compare all replicated measurements of varied treatments. The Tukey test was adopted to evaluate the significance of differences.

\section{RESULTS AND DISCUSSION}

\section{Soil, compost and biochar properties}

The physical and chemical characteristics of the three substrates are presented in Table 1 . Compared to the compost and soil, argan biochar showed the highest $\mathrm{pH}$, whereas the concentrations of $\mathrm{Ca}, \mathrm{Mg}, \mathrm{Na}$, nitrate and phosphorus were the highest for compost and the $\mathrm{K}$ concentrations were the highest for argan biochar. Soil showed the highest concentrations of $\mathrm{Fe}, \mathrm{Mn}, \mathrm{Cu}$ and $\mathrm{Zn}$.

\section{Changes in properties of soil after treatment}

Table 2 shows $\mathrm{pH}$, electrical conductivity (EC) and nutrient concentration of each treatment.

Table 1. Physical and chemical characteristics of soil, compost and argan biochar

\begin{tabular}{|l|c|c|c|}
\hline \multicolumn{1}{|c|}{ Specification } & Soil & Compost & Argan Biochar \\
\hline $\mathrm{pH}$ & 8.00 & 7.21 & 10.7 \\
\hline $\mathrm{EC} \mathrm{(milliS} \mathrm{cm-1)}$ & 0.317 & 1.40 & 4.83 \\
\hline $\mathrm{K}(\mathrm{ppm})$ & 50.77 & 489.13 & 1906.25 \\
\hline $\mathrm{Na}(\mathrm{ppm})$ & 6.79 & 510.28 & 339.2 \\
\hline $\mathrm{Ca}(\mathrm{ppm})$ & 65.45 & 81.82 & 4.8 \\
\hline $\mathrm{Mg}(\mathrm{ppm})$ & 95.33 & 1682.24 & 1258.92 \\
\hline $\mathrm{Fe}(\mathrm{ppm})$ & 7.50 & 0.79 & 0.00 \\
\hline $\mathrm{Mn}(\mathrm{ppm})$ & 12.08 & 0.08 & 0.04 \\
\hline $\mathrm{Cu}(\mathrm{ppm})$ & 0.33 & 0.16 & 0.00 \\
\hline $\mathrm{Zn}(\mathrm{ppm})$ & 0.69 & 0.03 & 0.04 \\
\hline $\mathrm{NaNO}_{3}(\mathrm{ppm})$ & 66.66 & 1466.66 & 100.00 \\
\hline $\mathrm{KH}_{2} \mathrm{PO}_{4}(\mathrm{ppm})$ & 0.50 & 1.33 & 0.33 \\
\hline
\end{tabular}


Table 2. Physicochemical properties of soil with/without treatments

\begin{tabular}{|l|c|c|c|c|c|c|c|c|c|c|}
\hline Specification & $\mathrm{pH}$ & $\mathrm{EC}$ & $\mathrm{K}$ & $\mathrm{Na}$ & $\mathrm{Ca}$ & $\mathrm{Mg}$ & $\mathrm{Fe}$ & $\mathrm{Mn}$ & $\mathrm{Cu}$ & $\mathrm{Zn}$ \\
\hline Soil & 8 & 0.317 & 0.275 & 0.259 & 0.478 & 0.424 & 3.6 & 9.7 & 1.3 & 1.8 \\
\hline S-C 2\% & 8.13 & 0.210 & 0.344 & 0.379 & 0.487 & 0.485 & 3.6 & 9.6 & 1.3 & 1.8 \\
\hline S-C 4\% & 8.33 & 0.219 & 0.464 & 0.505 & 0.509 & 0.562 & 3.7 & 9.6 & 1.4 & 1.7 \\
\hline S-C 6\% & 8.53 & 0.221 & 0.497 & 0.531 & 0.528 & 0.635 & 3.8 & 9.7 & 1.6 & 1.8 \\
\hline S-B 2\% & 8.20 & 0.272 & 0.533 & 0.279 & 0.478 & 0.452 & 3.6 & 9.7 & 1.3 & 1.7 \\
\hline S-B 4\% & 8.21 & 0.321 & 0.615 & 0.321 & 0.48 & 0.508 & 3.5 & 9.7 & 1.3 & 1.7 \\
\hline S-B 6\% & 8.23 & 0.408 & 0.785 & 0.492 & 0.486 & 0.549 & 3.5 & 9.6 & 1.2 & 1.6 \\
\hline S-C-B 2\% & 8.34 & 0.237 & 0.481 & 0.401 & 0.481 & 0.454 & 3.6 & 9.5 & 1.2 & 1.7 \\
\hline S-C-B 4\% & 8.42 & 0.270 & 0.629 & 0.438 & 0.488 & 0.525 & 3.7 & 9.6 & 1.4 & 1.9 \\
\hline S-C-B 6\% & 8.43 & 0.385 & 0.711 & 0.572 & 0.521 & 0.601 & 3.6 & 9.7 & 1.5 & 1.8 \\
\hline
\end{tabular}

EC (milliS cm-1), K (g/kg), Na (g/kg), Ca (g/kg), Mg (g/kg), Fe (mg/kg), Mn (mg/kg), Cu (mg/kg), Zn (mg/kg)

Soil-compost mixture at $6 \%$ had the highest value of $\mathrm{pH}$ whereas soil-biochar at $6 \%$ showed the highest $\mathrm{EC}$ value. The concentration of $\mathrm{K}$ was the highest for soil-biochar mixture at $6 \%$ whereas the concentration of $\mathrm{Na}$ was the highest for soilbiochar-compost mixture at $6 \%$. Soil-compost at $6 \%$ showed the highest content of $\mathrm{Mg}$ and $\mathrm{Ca}$, comparably to the rest of treatments. The concentration of $\mathrm{Fe}, \mathrm{Mn}, \mathrm{Cu}$ and $\mathrm{Zn}$ is the lowest among all treatments compared to unamended soil.

The contents of total nitrogen $(\mathrm{TN})$, phosphorus $(\mathrm{P})$, potassium $(\mathrm{K})$, total organic matter (TOM) and cation exchange capacity (CEC) for varied treatments are presented in Table 3. Compared to the soil and soil-biochar, the content of $\mathrm{N}, \mathrm{P}, \mathrm{TOM}$ and CEC were higher for soil-compost and soil-biochar-compost but the highest value was observed for soil-compost at $6 \%$. The $\mathrm{K}$ concentration was higher in the soil-biochar and soil-biochar-compost comparably to the soil and soil-compost but the highest value was observed for soil-biochar treatment at $6 \%$.

\section{Effects on quinoa growth and yield after different treatments}

The quinoa biomass harvested from the soilcompost, soil-biochar and soil-compost-biochar applications was higher compared to the unamended soil (Table 4). With compost, biochar and biochar-compost, the total leaf area, leaf number per plant and the biomass of different plant parts increased in all ratios compared to the unamended soil (Table 4). The biomass of leaves increased with all treatments compared to the soil, but the increase was not significant. A significant increase of seeds biomass (dry weight) was observed with biochar-compost treatment at $6 \%$ rates. The stem biomass also increased in all treatments in comparison to the soil, but the significant increase (dry weight) was observed with the biochar-compost treatment at $6 \%$ rates. A significant increase (dry weight) of tap root biomass was observed with the biochar-compost treatment at $6 \%$ rates. Leaf area, total biomass and plant height measurements of the quinoa plant grown in amended soil did not show any significant differences.

\section{Beta vulgaris growth using different treatments}

The sugar beet biomass collected from varied treatments is presented in Table 5. The total leaf number per plant and the total biomass increased with all treatments, as compared with the unamended soil excepting compost at $2 \%$ and compost-biochar at $6 \%$. Yet, the increase was not significant. The biomass of leaves was also higher in all treatments in comparison with the soil except for compost at $2 \%$; but the significant increase (dry weight) was noticed with compost-biochar

Table 3. Effects of varied treatments on NPK contents, TOM and CEC values

\begin{tabular}{|l|c|c|c|c|c|c|c|c|c|c|}
\hline \multicolumn{1}{|c|}{ Specification } & Soil & S-C 2\% & S-C 4\% & S-C 6\% & S-B 2\% & S-B 4\% & S-B 6\% & S-C-B 2\% & S-C-B 4\% & S-C-B 6\% \\
\hline TN (mg/kg) & 0.9 & 1.9 & 2.2 & 2.8 & 1.2 & 1.6 & 1.9 & 1.4 & 1.9 & 2.4 \\
P $(\mathrm{g} / \mathrm{kg})$ & 0.024 & 0.062 & 0.068 & 0.072 & 0.034 & 0.053 & 0.061 & 0.053 & 0.062 & 0.067 \\
\hline K $(\mathrm{g} / \mathrm{kg})$ & 0.275 & 0.344 & 0.464 & 0.497 & 0.533 & 0.615 & 0.785 & 0.481 & 0.629 & 0.711 \\
TOM (\%) & 5.01 & 6.72 & 9.18 & 12 & 5.62 & 6.32 & 6.49 & 6.32 & 7.82 & 9.03 \\
\hline CEC(meq/100g) & 13.6 & 17.6 & 18.4 & 18.72 & 16.6 & 16.84 & 17.4 & 16.82 & 17.6 & 17.80 \\
\hline
\end{tabular}


Table 4. Effects of different treatments with biochar, compost and their mixture on biomass of Chenopodium quinoa

\begin{tabular}{|c|c|c|c|c|c|c|c|c|c|c|}
\hline \multirow{3}{*}{$\begin{array}{l}\text { Plant variables } \\
\text { (units) }\end{array}$} & \multicolumn{9}{|c|}{ Treatment means (percent v/v) } & \multirow{3}{*}{ Soil } \\
\hline & \multicolumn{3}{|c|}{ Soil-Compost } & \multicolumn{3}{|c|}{ Soil-Biochar } & \multicolumn{3}{|c|}{ Soil-Compost-Biochar } & \\
\hline & S-C $2 \%$ & S-C 4\% & S-C 6\% & S-B $2 \%$ & S-B 4\% & S-B 6\% & $\begin{array}{c}\text { S-C-B } \\
2 \%\end{array}$ & $\begin{array}{c}\text { S-C-B } \\
4 \%\end{array}$ & $\begin{array}{c}\text { S-C-B } \\
6 \%\end{array}$ & \\
\hline Leaf number ( plant $^{-1}$ ) & 25.33 & 37.33 & 36 & 30.66 & 39.66 & 31.33 & 44 & 43.33 & 29 & 14.66 \\
\hline $\begin{array}{l}\sum \text { Leaf area } \\
\left(\mathrm{mm}^{2} \mathrm{mg}^{-1} \mathrm{dm} \text { plant }\right.\end{array}$ & 13.03 & 12.77 & 12.35 & 11.22 & 14.39 & 14.22 & 14.65 & 12.01 & 15.28 & 11.59 \\
\hline Biomass leaves ( $\mathrm{g} \mathrm{dm}$ ) & 0.31 & 0.44 & 0.29 & 0.38 & 0.31 & 0.22 & 0.50 & 0.55 & 0.35 & 0.18 \\
\hline Biomass stem (g dm) & 0.79 & 0.83 & 0.55 & 0.61 & 0.69 & 0.54 & 0.53 & 0.71 & $1.23^{*}$ & 0.41 \\
\hline Biomass seeds (g dm) & 0.922 & 1.04 & 0.70 & 1.00 & 0.73 & 0.77 & 0.77 & 1.11 & $1.52^{*}$ & 0.26 \\
\hline Biomass roots $(\mathrm{g} \mathrm{dm})$ & 0.05 & 0.04 & 0.04 & 0.05 & 0.06 & 0.04 & 0.04 & 0.06 & $0.09^{*}$ & 0.03 \\
\hline$\sum$ Biomass $(\mathrm{g} \mathrm{dm})$ & 2.02 & 2.31 & 1.54 & 1.99 & 1.73 & 1.53 & 1.8 & 2.37 & 3.1 & 0.85 \\
\hline Plant height $(\mathrm{cm})$ & 67.67 & 72.00 & 70.33 & 66.67 & 60.33 & 63.33 & 70.00 & 77.67 & 71.67 & 53.33 \\
\hline
\end{tabular}

* Difference is significant at the 0.05 level, compared to the unamended soil.

Table 5. Biomass of beta vulgaris measured in different treatments

\begin{tabular}{|l|c|c|c|c|c|c|c|c|}
\hline \multirow{3}{*}{ Plant variables (units) } & \multicolumn{7}{|c|}{ Treatment means (percent v/v) } & \multirow{2}{*}{ Soil } \\
\cline { 2 - 10 } & \multicolumn{3}{|c|}{ Soil-Compost (S-C) } & Soil-Biochar & \multicolumn{2}{|c|}{ Soil-Compost-Biochar (S-C-B) } \\
\cline { 2 - 9 } & S-C 2\% & S-C 4\% & S-C 6\% & S-B 6\% & S-C-B 2\% & S-C-B 4\% & S-C-B 6\% & \\
\hline Leaf number $\left(\right.$ plant $\left.^{-1}\right)$ & 6.50 & 8.67 & 8.67 & 8.33 & 7.33 & 10.00 & 6.67 & 7.00 \\
\hline Biomass leaves $(\mathrm{g} \cdot \mathrm{dm})$ & 0.12 & 0.45 & 0.45 & 0.40 & 0.38 & $0.51^{*}$ & 0.45 & 0.19 \\
\hline Biomass roots $(\mathrm{g} \cdot \mathrm{dm})$ & 0.13 & 0.20 & 0.81 & 0.71 & 0.53 & 0.82 & $1.13^{*}$ & 0.23 \\
\hline$\sum$ Biomass $(\mathrm{g} \cdot \mathrm{dm})$ & 0.25 & 0.65 & 1.26 & 1.11 & 0.91 & 1.33 & 1.58 & 0.42 \\
\hline
\end{tabular}

* Difference is significant at the 0.05 level compared to the unamended soil.

mixture at $4 \%$. The biomass of roots increased in all treatments when compared to the soil except compost at $2 \%$, but the significant increase (dry weight) was detected with biochar-compost mixture at $6 \%$. Leaf number and total biomass did not show any significant differences.

\section{Alfalfa growth under different treatments}

The alfalfa biomass collected from the amended and unamended soil was presented in Table 6 . The biomass of leaves and stems increased in all treatments in comparison with the unamended soil, excepting soil-biochar at 2\%. However, a significant increase (dry weight) was noticed with biochar-compost at 4\%. Roots and the total aboveground biomass also increased in all treatments when compared to the unamended soil, apart from soil-biochar at $2 \%$, but the increase was not significant. The total leaf area increased with all treatments, as compared to the soil except for soil-compost at $2 \%$ and soil-biochar at $4 \%$, but the increase was not significant. Leaf area,

Table 6. Biomass of Medicago sativa measured in different treatments

\begin{tabular}{|c|c|c|c|c|c|c|c|c|c|c|}
\hline \multirow{3}{*}{$\begin{array}{l}\text { Plant variables } \\
\text { (units) }\end{array}$} & \multicolumn{9}{|c|}{ Treatment means (percent v/v) } & \multirow{3}{*}{ Soil } \\
\hline & \multicolumn{3}{|c|}{ Soil-Compost (S-C) } & \multicolumn{3}{|c|}{ Soil-Biochar (S-B) } & \multicolumn{3}{|c|}{ Soil-Compost-Biochar (S-C-B) } & \\
\hline & $\begin{array}{l}S-C \\
2 \%\end{array}$ & $\begin{array}{l}S-C \\
4 \%\end{array}$ & $\begin{array}{l}S-C \\
6 \%\end{array}$ & $\begin{array}{l}S-B \\
2 \%\end{array}$ & $\begin{array}{l}\text { S-B } \\
4 \%\end{array}$ & $\begin{array}{l}\text { S-B } \\
6 \%\end{array}$ & $\begin{array}{c}\text { S-C-B } \\
2 \%\end{array}$ & $\begin{array}{c}\text { S-C-B } \\
4 \%\end{array}$ & $\begin{array}{c}\text { S-C-B } \\
6 \%\end{array}$ & \\
\hline $\begin{array}{l}\sum \text { Leaf area } \\
\left(\mathrm{mm}^{2} \mathrm{mg}^{-1} \mathrm{dm}_{\text {plant- }}{ }^{-1}\right)\end{array}$ & 11.03 & 13.11 & 17.46 & 13.06 & 11.51 & 13.75 & 14.25 & 13.69 & 15.08 & 12.98 \\
\hline Biomass leaves ( $\mathrm{g} \mathrm{dm}$ ) & 0.29 & 0.30 & 0.47 & 0.19 & 0.24 & 0.26 & 0.40 & $0.75^{\star}$ & 0.62 & 0.23 \\
\hline Biomass stems ( $\mathrm{g} \mathrm{dm})$ & 0.45 & 0.53 & 0.48 & 0.22 & 0.40 & 0.42 & 0.53 & $0.94^{*}$ & 0.70 & 0.25 \\
\hline Biomass roots $(\mathrm{g} \mathrm{dm})$ & 0.41 & 0.64 & 0.30 & 0.22 & 0.36 & 0.37 & 0.33 & 0.70 & 0.47 & 0.30 \\
\hline $\begin{array}{l}\sum_{(\mathrm{g} \text { dm })} \text { abovground Biomass } \\
\end{array}$ & 0.74 & 0.83 & 0.95 & 0.41 & 0.64 & 0.68 & 0.93 & 1.69 & 1.32 & 0.48 \\
\hline
\end{tabular}

* Difference is significant at the 0.05 level compared to the unamended soil. 
roots biomass and total aboveground biomass did not show any significant differences.

In varied treatment, the growth of quinoa, sugar beet and alfalfa plant parts was enhanced as compared to untreated soil, especially when combining compost and biochar. Because biochar is known to increase the $\mathrm{pH}$ value of soils (Ohsowski et al., 2012, Hazelton and Murphy, 2007), the compost-biochar treatments could be responsible for maintaining the highest $\mathrm{pH}$ values to reach an adequate $\mathrm{pH}$ for plant growth. These $\mathrm{pH}$ values in the compost-biochar treatments may be one of the factors that allow plants to have a higher quantity of biomass during the experiment. The values for $\mathrm{K}, \mathrm{Na}$ and $\mathrm{Mg}$ for the soil are very low. When soil was treated with compost and biochar, the values for these nutrients increased. Thus, plants could improve their biomass because of the available nutrients in compost-biochar applications. This is in agreement with previous findings (Jones et al., 2016, Hammer et al., 2015, Lehmann et al., 2011). In addition, during the pyrolysis process, biochar can be contaminated by inorganic substances. This was not observed in our study, where soil has much greater heavy metal content than biochar and compost.

Furthermore, argan shells biochar could be used to reduce the use of inorganic soluble K fertilizers as it is an important source of K. Other studies have stressed that adding biochar reinforces the benefits of compost (Paradelo et al., 2016, Sorrenti and Toselli, 2016, Zainul et al., 2017) which is in agreement with the obtained results. In fact, combining biochar and compost ameliorate soil structure and nutrients bioavailability since biochar helps in retaining efficiently the nutrients in compost and slowly releases them to plants over time (Karer et al., 2015, Paradelo et al., 2016). This demonstrates that biochar has a constant benefit on agricultural soil fertility and plant growth.

The values for cations, total nitrogen, phosphorus, potassium, total organic matter and cation exchange capacity were very low for unamended soil. However, when the soil was treated with argan biochar and compost, these values increased. The observed increase in the nitrogen content is vital for soil structure quality and plant production (Christensen, 2004). The cation exchange capacity has an important role in stabilizing soil structure, soil $\mathrm{pH}$ and nutrient bioavailability (Hazelton and Murphy, 2007, Karer et al., 2015, Paradelo et al., 2016). Thus, it has been demonstrated in this study that the observed quinoa, sugar beet and alfalfa biomass improvement in soil mixed with argan biochar and compost can be explained by the increase of the bioavailable nutrient content during the three plants growth. Moreover, biochar is now considered as a good option for carbon sequestration in soils instead of being sent out into the atmosphere, and hence contributing to the moderation of global climate change (Lorenz and Lal, 2014, Smith, 2016). Thus, applying biochar and compost in agricultural soils is a good solution to recycle organic wastes, providing environmental merits and decreasing the use of chemical fertilizers.

\section{CONCLUSIONS}

Appling argan biochar and compost in mixture has a positive effect in providing essential nutrients for plants, which is beneficial for agricultural soils. Moreover, this study reveals the merits of the two amendments used in different proportions on quinoa, sugar beet and alfalfa growth. These effects were more pronounced when the two organic amendments were used in combination, which could be explained by the increase of bioavailable nutrient content during the growth of three plants.

\section{Acknowledgments}

The authors would like to express their deepest gratitude and acknowledgement to the Hassan II Agronomic and Veterinary Institute, Agadir, Morocco for its financial assistance.

\section{REFERENCES}

1. Agegnehu G., Nelson P.N., Bird M.I. 2016. The effects of biochar, compost and their mixture and nitrogen fertilizer on yield and nitrogen use efficiency of barley grown on a Nitisol in the highlands of Ethiopia. Sci. Total Environ., 569-570, 869-879.

2. Amini S., Ghadiri H., Chen C., Marschner P. 2016. Salt-affected soils, reclamation, carbon dynamics, and biochar: a review. J. Soil Sediment., 16, 939-953.

3. Badraoui M., Agbani M., Soudi B. 2000. Évolution de la qualité des sols sous mise en valeur intensive au Maroc. Conférence 'Intensification agricole et qualité des sols et des eaux', Rabat, Maroc, 2-3 Novembre (In french). 
4. Blakemore L.C., Searle P.L., Daly B.K. 1987. Methods for Chemical Analysis of Soils. New Zealand Soil Bureau Scientific Report, 80, 103 p.

5. Bouqbis L., Daoud S., Kory H.W., Kammann C.I., Ainlhout L.F.Z., Harrouni M.C. 2016. Biochar from argan shells: production and characterization. Int. J. Recycl. Org. Waste Agric., 5, 361-365.

6. Butnan S., Deenik J.L., Toomsan B., Antal M.J., Vityakon P. 2015. Biochar characteristics and application rates affecting corn growth and properties of soils contrasting in texture and mineralogy. Geoderma, 237, 105-116.

7. Christensen B.T. 2004. Tightening the nitrogen cycle. In: Schjonning, P., Elmholt, S., Christensen, B.T. (Eds.), Managing Soil Quality, Challenges in Modern Agriculture. CABI Publishing. London, UK, pp. 44-66.

8. Haider G., Steffens D., Moser G., Müller C., Kammann C.I. 2017. Biochar reduced nitrate leaching and improved soil moisture content without yield improvements in a four-year field study. Agriculture Ecosystems and Environment, 237, 80-94.

9. Hammer E.C., Forstreuter M., Rillig M.C., Kohler J. 2015. Biochar increases arbuscular mycorrhizal plant growth enhancement and ameliorates salinity stress. Appl. Soil Ecol., 96, 114-121.

10. Hazelton P., Murphy B. 2007. Interpreting Soils Test Resulting. What do All the Numbers Mean? CSIRO Publishing, Australia.

11. Jones D.L., Rousk J., Edwards-Jones G., DeLuca T.H., Murphy D.V. 2012. Biochar- mediated changes in soil quality and plant growth in a three year field trial. Soil Biol. Biochem., 45, 113-124.

12. Jones S., Bardos R.P., Kidd P.S., Mench M., de Leij F., Hutchings T., Cundy A., Joyce C., Soja G., Friesl-Hanl W., Herzig R. 2016. Biochar and compost amendments enhance copper immobilisation and support plant growth in contaminated soils. J. Environ. Manage., 171, 101-112.

13. Karer J., Wawra A., Zehetner F., Dunst G., Wagner M., Pavel P.B., Puschenreiter M., Friesl-Hanl W., Soja G. 2015. Effects of biochars and compost mixtures and inorganic additives on immobilisation of heavy metals in contaminated soils. Water Air Soil Pollut., 226, 342-354.

14. Lehmann J., Rillig M.C., Thies J., Masiello C.A., Hockaday W.C., Crowley D. 2011. Biochar effects on soil biota: a review. Soil Biol. Biochem., 43, 1812-1836.

15. Li Y., Hu S., Chen J., Müller K., Li Y., Fu W., Lin Z., Wang H. 2018. Effects of biochar application in forest ecosystems on soil properties and greenhouse gas emissions: a review. Journal of Soils and Sediments, 18, 546-563.

16. Lindsay W.L., Norvell W.A., 1978. Development of a DTPA soil test for zinc, iron, manganese, and copper. Soil Science Society of America Journal, $42,421-428$.

17. Lorenz K., Lal R. 2014. Biochar application to soil for climate change mitigation bysoil organic carbon sequestration. J. Plant. Nutr. Soil. Sci., 177, 651-670.

18. Metson A.J. 1956. Methods of chemical analysis for soil survey samples. N Z Soil Bur Bull n 12 .

19. Mills R.T., Gavazov K.S., Spiegelberger T., Johnson D., Buttler A. 2014. Diminished soil functions occur under simulated climate change in a sup-alpine pasture, but heterotrophic temperature sensitivity indicates microbial resilience. Sci. Total Environ., 473, 465-472.

20. Ohsowski B.M., Klironomos J.N., Dunfield K.E., Hart M.M. 2012. Potential of soil amendments for restoring severely disturbed grasslands. Appl. Soil Ecol., 60, 77-83.

21. Paradelo R., Vázquez-Nion D., Silva B., González Á., Barral M.T. 2016. Acidification of

22. mixtures of granite powder and compost for reuse in plant production. Comp. Sci. Uti., 24, 1-10.

23. Perez-Esteban J., Escolastico C., Masaguer A., Moliner A. 2012. Effects of sheep and horse manure and pine bark amendments on metal distribution and chemical properties of contaminated mine soils. Eur. J. Soil Sci., 63, 733-742.

24. Rajkovich S., Enders A., Hanley K., Hyland C., Zimmerman A.R., Lehmann J. 2012. Corn growth and nitrogen nutrition after additions of biochars with varying properties to a temperate soil. Biol. Fertil. Soils, 48 (3), 271-284.

25. Ramzani P.M.A., Iqbal M., Kausar S., Ali S., Rizwan M., Virk Z.A. 2016. Effect of different amendments on rice (Oryza sativa L.) growth, yield, nutrient uptake and grain quality in Ni-contaminated soil. Environ. Sci. Pollut. Res., 23, 18585-18595.

26. Schlesinger W.H., Dietze M.C., Jackson R.B., Phillips R.P., Rhoades C.C., Rustad L.E., Vose J.M. 2015. Forest biogeochemistry in response to drought. Glob. Change Biol., 22, 2318-2328.

27. Schmidt H.P., Kammann C., Niggli C., Evangelou M.W.H., Mackie K.A., Abiven S. 2014. Biochar and biochar-compost as soil amendments to a vineyard soil: Influences on plant growth, nutrient uptake, plant health and grapequality. Agriculture, Ecosystems and Environment, 191, 117-123.

28. Smith P. 2016. Soil carbon sequestration and biochar as negative emission tech-nologies. J. Glob. Change Biol., 22, 1315-1324.

29. Solaiman Z.M., Anawar H.M. 2015. Application of biochars for soil constraints: challenges and solutions. Pedosphere, 25, 631-638. 
30. Sorrenti G., Toselli M. 2016. Soil leaching as affected by the amendment with biochar and compost. Agriculture, Ecosystems and Environment, 226, 56-64.

31.Zainul A., Kory H.W., Huchzermeyer B., Gul B., Khan M.A. 2017. Impact of a Biochar or a CompostBiochar Mixture on Water relation, Nutrient uptake and Photosynthesis of Phragmites karka. Pedosphere. https://doi.org/10.1016/S1002-0160(17)60362-X.
32. Sorrenti G., Toselli M. 2016. Soil leaching as affected by the amendment with biochar and compost. Agriculture, Ecosystems and Environment, 226, 56-64.

33. Van Ranst E., Verloo M., Demeyer A., Pauwels M.J. 1999. Manual for the Soil Chemistry and Fertility Laboratory-Analytical Methods for Soils and Plants, Equipment, and Management of Consumables. NUGI 835, Ghent, Belgium, 243 p. 